\title{
Mechanical performance assessment of half warm recycled asphalt mixes containing up to $100 \%$ RAP
}

\author{
J. M. Lizárraga ${ }^{\mathrm{a}}$, A. Jiménez del Barco-Carrión ${ }^{\mathrm{b}} \bowtie$, A. Ramírez ${ }^{\mathrm{a}}$, \\ P. Díaz ${ }^{\text {a }}$, F. Moreno-Navarro ${ }^{c}$, M. C. Rubio
}

a. Department of research, development and innovation (R\&D+i) Sacyr construcción, (Madrid, Spain)

b. Nottingham Transportation Engineering Centre (NTEC), University of Nottingham, (Nottingham, United Kingdom) c. Laboratorio de Ingeniería de la Construcción (labIC.ugr), ETSICCP, Universidad de Granada, (Granada, Spain) $\bowtie$ ajbc@ugr.es

Received 8 June 2016

Accepted 22 November 2016

Available on line dd month year

\begin{abstract}
The use of Half Warm Mixes with high Reclaimed Asphalt content (HWMRA) has the potential to generate significant environmental advantages such as the reduction in consumption of natural resources and the emission of gases into the atmosphere. This paper therefore focuses on demonstrating the viability of using these types of mixes in wearing courses. For this purpose, an HWMRA with $70 \%$ and $100 \%$ Reclaimed Asphalt Pavement (RAP) and emulsion were designed in the laboratory. The performance of the mixes was then assessed and compared with that of conventional Hot Mix Asphalt. In a second stage, the mixes were manufactured in-plant, and laid and compacted in an Accelerated Pavement Test track. The cores were then extracted and tested for stiffness modulus and resistance to fatigue. The results from the tests conducted with both the laboratory specimens and the cores showed that the performance of HWMRA is comparable to that of HMA. These findings encourage greater confidence in promoting the use of these types of sustainable asphalt mixes.
\end{abstract}

KEYWORDS: Asphalt; Recycling; Characterization; Fatigue; Mechanical properties

Citation/Citar como: Lizárraga, J.M.; Jiménez del Barco-Carrión, A.; Ramírez, A.; Díaz, P.; Moreno-Navarro, F. Rubio, M.C. (2017) Mechanical performance assessment of half warm recycled asphalt mixes containing up to $100 \%$ RAP. Mater. Construcc. 67 [327], e129 http://dx.doi.org/10.3989/mc.2017.05116

RESUMEN: Evaluación del comportamiento mecánico de mezclas asfálticas templadas con $100 \%$ de material reciclado. La utilización de mezclas asfálticas templadas con alto contenido de asfalto reciclado (HWMRA) conlleva ventajas medioambientales como la reducción del consumo de recursos naturales y la emisión de gases a la atmósfera. Este artículo se centra en mostrar la viabilidad de este tipo de mezclas para capas de rodadura. Para ello, se diseñaron mezclas HWMRA con $70 \%$ y $100 \%$ de asfalto reciclado en el laboratorio y se evaluó y comparó su comportamiento con una mezcla caliente convencional. En una segunda etapa, las mezclas fueron fabricadas en planta, extendidas y compactadas en una pista de ensayo acelerado de pavimentos. A continuación, se extrajeron testigos y se ensayaron para conocer su módulo de rigidez y resistencia a fatiga. Tanto los resultados de laboratorio como tras la fabricación en planta y puesta en obra mostraron que el comportamiento de mezclas HWMRA es comparable al de mezclas calientes convencionales. Dicha conclusión puede aportar confianza a este tipo de mezclas sostenibles promoviendo su mayor utilización.

PALABRAS CLAVE: Asfalto; Reciclado; Caracterización; Fatiga; Propiedades mecánicas

ORCID ID: J.M. Lizárraga (http://orcid.org/0000-0002-6566-3660); A. Jiménez del Barco-Carrión (http://orcid.org/00000002-2135-5455); A. Ramírez (http://orcid.org/0000-0003-3057-8367); P. Díaz (http://orcid.org/0000-0003-2780-7202); F. Moreno-Navarro (http://orcid.org/0000-0001-6758-8695); M.C. Rubio-Gámez (http://orcid.org/0000-0002-1874-5129)

Copyright: (C) 2017 CSIC. This is an open-access article distributed under the terms of the Creative Commons Attribution License (CC BY) Spain 3.0. 


\section{INTRODUCTION}

Environmental concerns regarding the production of asphalt mixes are currently related to the use of virgin materials and the high temperatures used to manufacture Hot Mix Asphalt (HMA), which generate harmful emissions $(1,2)$. For the purpose of overcoming these issues, various alternatives have been proposed by both researchers and companies. One alternative for reducing the consumption of virgin materials is to introduce the use of recycled materials from pavements (Reclaimed Asphalt Pavement, commonly referred to as RAP) or demolition debris (3) in the production of new mixes.

In recent years, RAP has been widely used in the production of new asphalt mixes, and its high resistance to some of the most common distresses in pavements (such as rutting) has encouraged its use in high quantities $(\geq 30 \%)$. Mixes containing RAP are stiffer and have higher complex modulus than those which contain only virgin materials (4), due to the hardening process suffered by the binder in the RAP during its service life. On account of the increased stiffness of the binder, RAP mixes usually exhibit better (or at least equivalent) resistance to rutting than conventional mixes (5). However, there still remains some uncertainty regarding the fatigue cracking behaviour of mixes using RAP. Whilst a number of studies have shown that these mixes are less resistant to fatigue than conventional mixes due to the stiff and brittle binder of the RAP (6), other results are rather less conclusive. For instance, Shu et al. (7) examined the performance of mixes containing 10, 20, and 30\% RAP using various fatigue failure criteria. They found that, depending on the criterion used, the addition of RAP appeared to either increase or decrease the fatigue life of pavements. Further, Hajj et al. (5) reported that the inclusion of RAP could result in either poorer or better fatigue resistance depending on the source or contents of this material. However, contrary to popular belief, some authors have found that the use of RAP could lead to significant improvements in the fatigue life of mixes (8-10). A more in-depth analysis of the fatigue behaviour of these mixes is therefore of critical importance for ensuring their satisfactory performance in the field.

In order to diminish the harmful emissions released into the atmosphere when HMA is produced, there have been attempts to reduce the manufacturing temperatures of asphalt mixes by treating the bitumen to reduce its viscosity at the time of mixing. To achieve this, the bitumen is either foamed or emulsified, and, depending on the required range of temperature reduction, warm $\left(110-140^{\circ} \mathrm{C}\right)$, halfwarm (lower than $100{ }^{\circ} \mathrm{C}$ ) and cold (room temperature) mixes can be produced. Moreover, the reduction in manufacturing temperatures leads to a decrease in energy consumption and hence economic costs $(11,12)$. In this paper, Half Warm Mix Reclaimed Asphalt (HWMRA) is studied using emulsified bitumen with high RAP content (up to $100 \%$ ).

In spite of the environmental and economic advantages of using these types of mixes, a number of questions remain regarding their performance. This issue prevents their widespread use, particularly in wearing courses (due to the high requirements of this layer). Recent work has therefore focused on showing that reducing temperatures to within the warm/half-warm range and introducing RAP should not compromise the performance of the mixes (13-15). In particular, mixes containing a high RAP content manufactured with low temperature technologies have been shown to have better (or equivalent) fatigue and rutting resistance when compared with HMA, without any adverse effects on water sensitivity $(7,16,17)$. Field experiences have also demonstrated the suitability of combining the use of RAP with lower manufacturing temperatures (18).

However, many of the studies found in the literature have focused on warm or cold - as opposed to half-warm - technologies. The latter can be regarded as an intermediate step, in which the temperature is lower than that of warm production whilst avoiding the issues associated with cold production. A further problem is that the majority of asphalt plants are currently not fully equipped for manufacturing mixes at low temperatures or for introducing high quantities of RAP.

In the present study, HWMRA for wearing courses was produced in the laboratory and then upscaled to plant manufacturing in a prototype plant that is equipped to deal with complete recycling and half-warm production temperatures. The main objective of this investigation is to compare the mechanical performance of Half Warm Mix Reclaimed Asphalt (HWMRA) with high-RAP content (up to $100 \%$ ) with that of a conventional HMA mixture. Performance is compared at both laboratory level and after the plant manufacture, laying, and compaction in the field in order to strengthen confidence in using these environmentally sound techniques.

\section{MATERIALS}

For the purpose of this research, three asphalt mixes were employed. In particular, two HWMRA mixes were used along with an HMA, which served as a reference. The three mixes were designed in the laboratory as Asphalt Concrete (AC) 16 for surface layers.

\subsection{Half Warm Recycled Asphalt (HWRA) mixtures}

Mixes with $70 \%$ and $100 \%$ RAP and emulsion were manufactured in the laboratory. The RAP used 
TABLE 1. RAP binder content and binder recovery characterisation

\begin{tabular}{|c|c|c|c|c|}
\hline \multirow[b]{2}{*}{ RAP Fraction } & \multicolumn{2}{|c|}{ Binder content $(\%)(19)$} & \multicolumn{2}{|c|}{ Recovery of asphalt binder for its characterisation (20) } \\
\hline & $\%$ binder/mixture & $\%$ binder/aggregate & Penetration at $25^{\circ} \mathrm{C}(\mathrm{dmm})$ & Softening point $\left({ }^{\circ} \mathrm{C}\right)$ \\
\hline $0 / 5$ & 7.67 & 8.31 & \multirow[b]{2}{*}{10} & \multirow[b]{2}{*}{81.8} \\
\hline $5 / 25$ & 3.39 & 3.51 & & \\
\hline
\end{tabular}

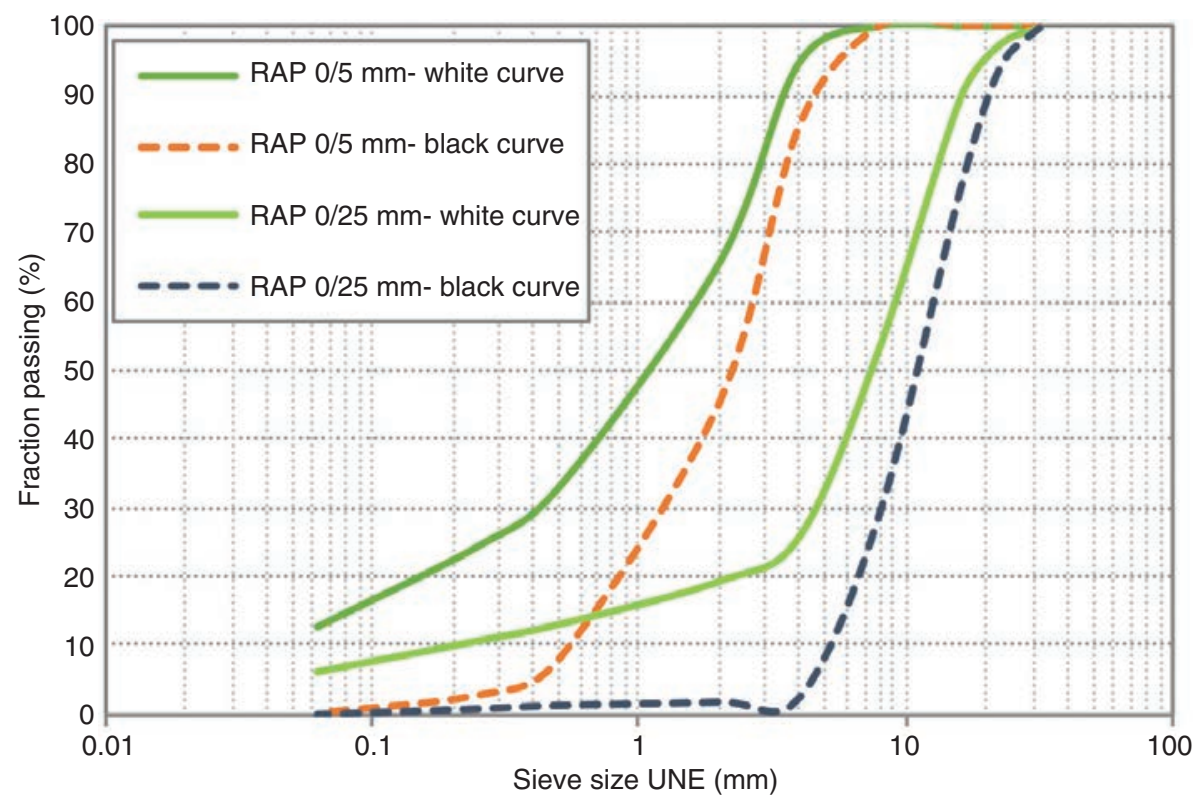

FIGURE 1. Black and white curves for the RAP fractions

in the present study was divided into fine $(0 / 5 \mathrm{~mm})$ and coarse $(5 / 25 \mathrm{~mm})$ fractions. Both fractions were characterised in terms of binder content (19), binder recovery (20) and black and white curves. The black curve represents the RAP gradation containing the aged binder while the white curve represents the RAP gradation once the binder has been extracted. These data are displayed in Table 1 and Figure 1 respectively. Siliceous aggregates were selected as virgin materials for the $70 \%$ RAP mixture using the $6 / 12$ and $12 / 18 \mathrm{~mm}$ fractions. A description of these aggregates is shown in Table 2.

Both of the HWMRA mixtures were manufactured using bitumen emulsion. Specifically, Slow Setting Cationic Bitumen Emulsion (SSCBE- 1h, C67B3 RECITEMP) with high residue bitumen content ranging from 65 to $69 \%$ of the total weight of the mixture was used. Table 3 shows the general technical specifications of this bituminous emulsion.

The final compositions of the mixtures are shown in Table 4, which details the percentages of each of the RAP and virgin aggregate fractions used, along with the emulsion content. In accord with the proportions shown in Table 4, the final gradations of the mixes are shown in Figure 2, together with AC16 thresholds.

\subsection{Hot Mix Asphalt mixture}

A conventional HMA was selected as a reference for comparison with the HWMRA. The Virgin aggregates presented in Table 2 were used, following the proportions displayed in Table 5. The final gradation of the HMA to produce an AC16 is shown in Figure 2. The virgin bitumen selected was $35 / 50$ penetration grade, having $42 \mathrm{dmm}$ as penetration at $25^{\circ} \mathrm{C}(22)$ and $55.6^{\circ} \mathrm{C}$ as the softening point (24).

\section{METHODOLOGY}

This investigation was divided into three phases. In the first phase the mixes were manufactured, compacted and studied in the lab. In the second phase, they were up-scaled to plant manufacturing, laying, compaction, and coring in the CEDEX test track, located in Madrid, Spain. Finally, the cores were tested in the laboratory. The details of each phase are presented in the following sections. 
TABLE 2. Characterisation of virgin aggregates

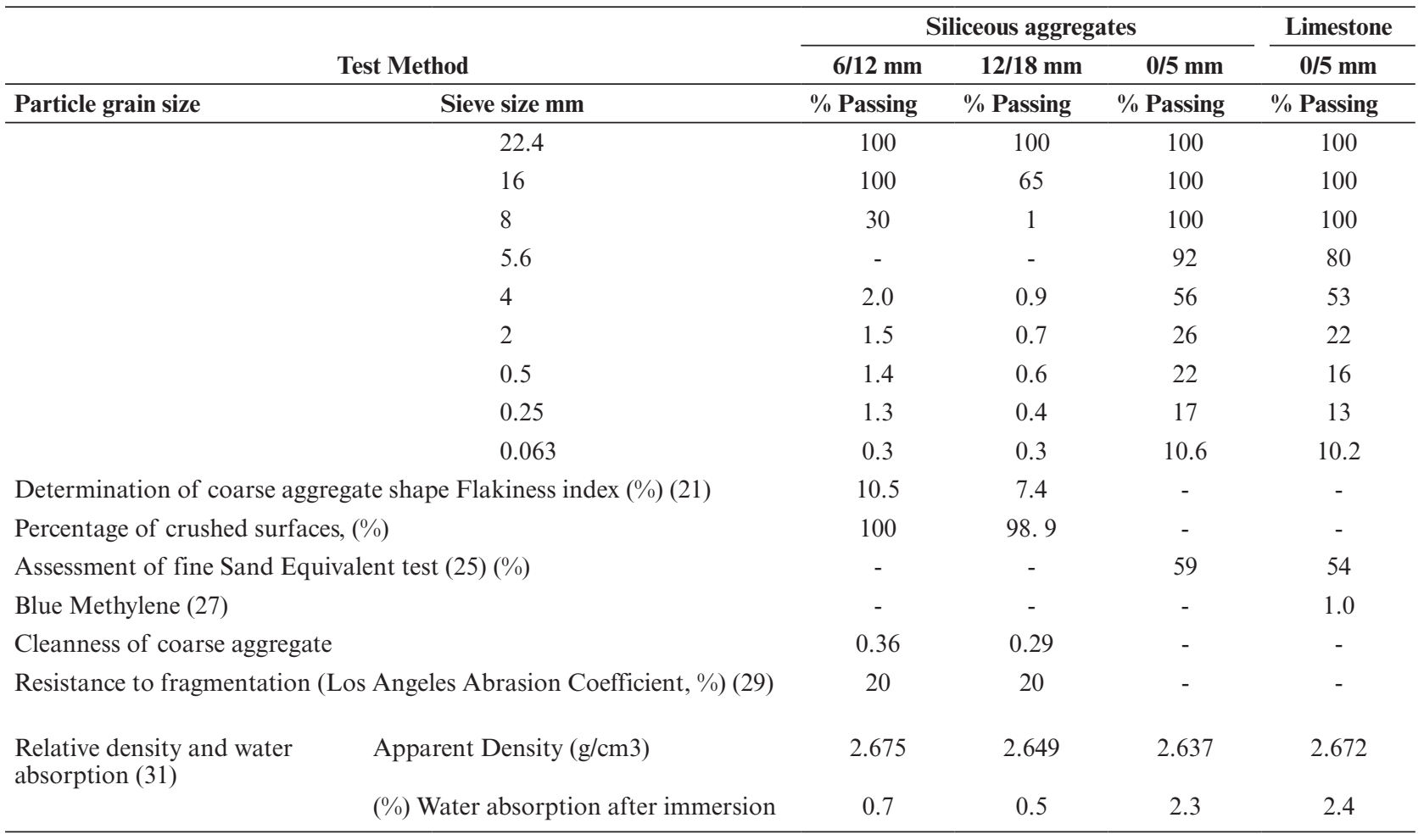

TABLE 3. General technical specification of C67B3 RECITEMP emulsion

\begin{tabular}{|c|c|c|c|}
\hline Properties & Unit & Test Method & Specification \\
\hline Particle polarity & - & EN 1430 & Positive \\
\hline Breaking value & - & EN 13075-1 & $50-100$ \\
\hline Binder content (from the water content) & $\%$ & EN 1428 & $65-69$ \\
\hline Residual binder by distillation & $\%$ & EN 1431 & $\geq 65$ \\
\hline Oil distillate content by distillation & $\%$ & EN 1431 & $\leq 2$ \\
\hline Efflux time, $4 \mathrm{~mm}$ at $40{ }^{\circ} \mathrm{C}$ & $\mathrm{s}$ & EN 12846 & $50-100$ \\
\hline Residue on sieving & $\%$ & EN 1429 & $\leq 0,1$ \\
\hline Setting tendency & $\%$ & EN12847 & $\leq 10$ \\
\hline Adhesiveness by water immersion & $\%$ & EN13614 & $\geq 90$ \\
\hline \multicolumn{4}{|c|}{ Recovery of binder by Evaporation (33) } \\
\hline Penetration at $25^{\circ} \mathrm{C}$ & $0,1 \mathrm{~mm}$ & EN 1426 & $\leq 100$ \\
\hline Softening point & ${ }^{\circ} \mathrm{C}$ & EN1427 & $\geq 50$ \\
\hline
\end{tabular}

TABLE 4. Composition of HWMRA mixtures

\begin{tabular}{lccc}
\hline & & \multicolumn{2}{c}{ Composition (\%) } \\
\cline { 3 - 4 } Materials & Fraction mm & HWMRA 70 \% RAP & HWMRA 100 \% RAP \\
\hline RAP & $0 / 5$ & 35 & 30 \\
RAP & $5 / 25$ & 35 & 70 \\
Virgin aggregates & $6 / 12$ & 18 & - \\
& $12 / 18$ & 12 & - \\
Emulsion & & $4.0 \%$ & $2.50 \%$ \\
\hline
\end{tabular}




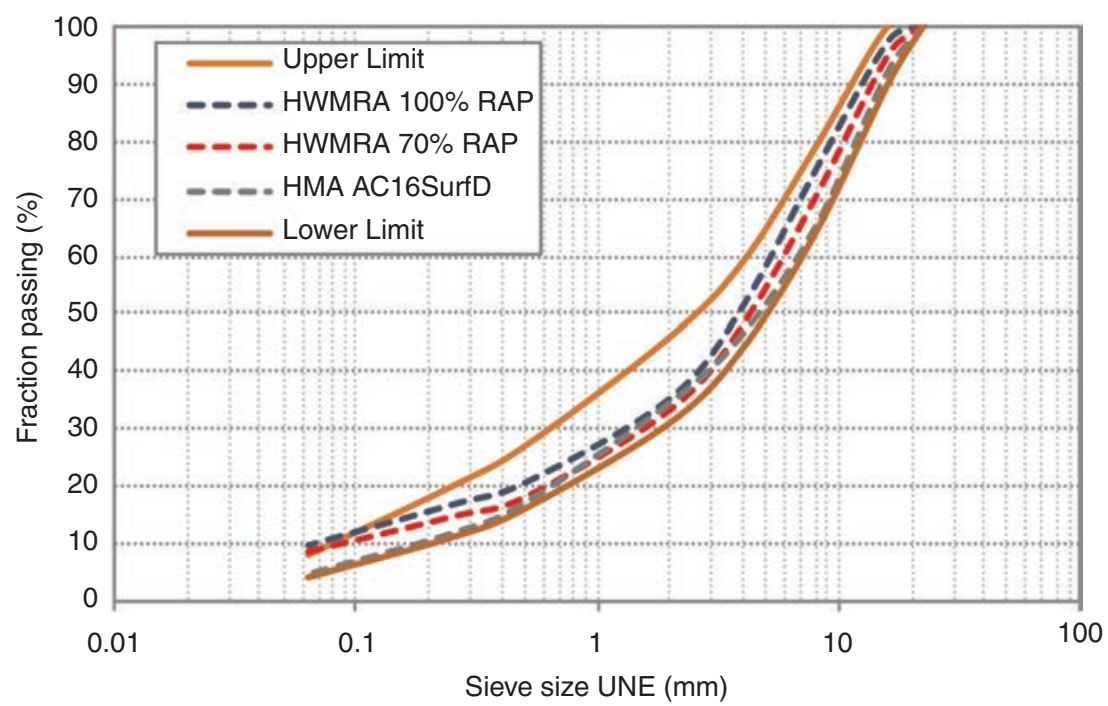

FIgURE 2. Gradation of the HWMRA and HMA mixtures

TABLE 5. HMA mixture composition

\begin{tabular}{llcc}
\hline Mix & Aggregates Nature & Fraction $(\mathbf{m m})$ & Composition (\%) \\
\hline HMA AC16D & Siliceous & $0 / 5$ & 36 \\
& Limestone & $0 / 5$ & 25 \\
& Siliceous & $5 / 12$ & 29 \\
& Siliceous & $12 / 18$ & 10 \\
& & Binder & 5 \\
\hline
\end{tabular}

\subsection{Preliminary laboratory study}

The HWMRA mixes were manufactured in the laboratory, heating the RAP and virgin aggregates at $115-120^{\circ} \mathrm{C}$ and the emulsion at $60-65^{\circ} \mathrm{C}$. Both the $70 \%$ and $100 \%$ RAP mixes were compacted in a Superpave Gyratory Compactor (SGC) at $70^{\circ} \mathrm{C}$. The number of gyros applied to each of the RAP mixtures was adapted to obtain a final void content of $4-6 \%$. Thus, for the $70 \%$ RAP content mixture the number of gyros was 90 , while for the $100 \%$ RAP mixture this number was 65 . This void content was achieved for both mixes without any workability problems.

The HMA was manufactured at $160^{\circ} \mathrm{C}$ and compacted in a Marshall compactor at $150^{\circ} \mathrm{C}$. The target void content was the same as that for the HWMRA, in order to reliably compare their mechanical properties. The three mixes were tested for stiffness modulus at $20^{\circ} \mathrm{C}(26)$. In addition, water sensitivity was tested by recording the retained indirect tensile strength at $15{ }^{\circ} \mathrm{C}$ after wet conditioning (28), and resistance to permanent deformation was assessed at $60{ }^{\circ} \mathrm{C}$ in the wheel tracker (30) after roller compaction for the production of slabs. The performance of the HWMRA could then be compared to that of the reference mix.

\subsection{Field experience}

In this phase of the investigation the mixes were manufactured in a prototype continuous asphalt mixing plant equipped to produce $100 \%$ RAP mixes. This plant has a flow parallel drum with two point material entries for different RAP fractions as well as a thermally insulated combustion chamber with delayed effect. The asphalt plant has a set of separate cold storage feeding bins for storing the various RAP fractions, and is also equipped with a volumetric weighbridge system with a measuring accuracy of $\pm 0.5 \%$. The fine fraction $(0 / 5 \mathrm{~mm})$ and coarse fraction $(5 / 25 \mathrm{~mm})$ were screened and fractionated (oversized clumps greater than $60 \mathrm{~mm}$ were separated and rejected) with the aim of accurately reproducing the target grading curve size designed in the laboratory at the asphalt mixing plant.

The parallel flow drum has two distinct entry points for administering specific treatments to each RAP fraction and for driving off the moisture content in the fine fraction. The coarse fraction $(5 / 25 \mathrm{~mm})$ was fed into the drum at one end, whereas the fine fraction $(0 / 5 \mathrm{~mm})$, with a higher percentage of bitumen, was introduced at the centre of the drum. In the case of the HWMRA with 
(a)

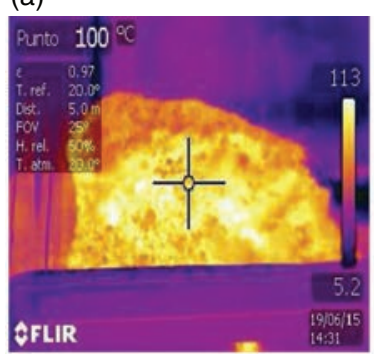

(b)

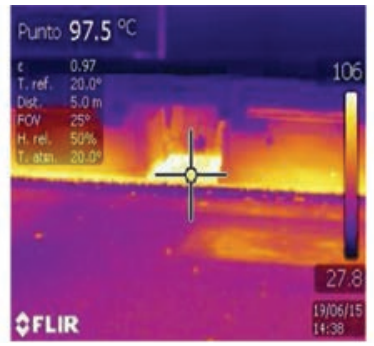

(c)

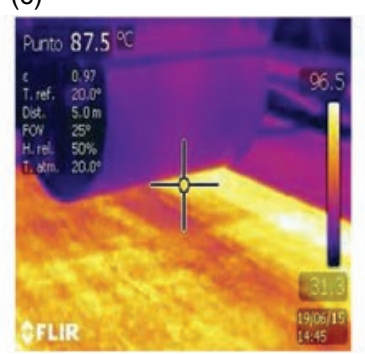

(d)

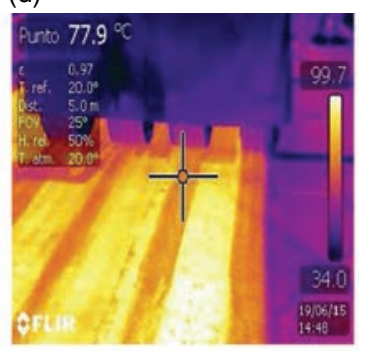

FIGURE 3. a) Delivery truck at the job site; b) Beginning of paving; c) Vibratory roller compaction; d) Pneumatic tyre roller compaction

TABLE 6. Volumetric properties, stiffness modulus and water sensitivity results

\begin{tabular}{lccc}
\hline & HWMRA 100 \% RAP & HWMRA 70 \% RAP & HMA AC16D \\
\hline Compaction temperature, ${ }^{\circ} \mathrm{C}$ & 70 & 70 & 150 \\
Maximum density, g/cm & & 2.433 & 2.460 \\
Apparent density, g/cm ${ }^{3}$ & 2.440 & 2.315 & 2.341 \\
\% Air Void Content & 2.325 & 4.85 & 4.84 \\
Stiffness modulus at $20{ }^{\circ} \mathrm{C}, \mathrm{MPa}$ & 4.71 & 5226 & 7600 \\
ITSw, MPa & 6733 & 2.84 & 2.72 \\
ITSd, MPa & 2.97 & 2.51 & 2.61 \\
\% ITSR & 2.67 & 88.3 & 95.8 \\
\hline
\end{tabular}

$70 \%$ RAP, the virgin aggregates were initially fed into the drum dryer at the same point as the RAP $(5 / 25 \mathrm{~mm})$. The asphalt mixer was positioned below the drum dryer to extend the mixing times and to improve the coating and adhesion between the RAP material and the aggregates. A slow-setting cationic bituminous emulsion was then added to the asphalt and mixed together with the RAP material.

The temperature was monitored during transit, paving and compaction of the HWMRA (Figure 3). After manufacture, the mix was delivered to the job site (by truck) at a temperature of $100{ }^{\circ} \mathrm{C}$. The paving process then began at a temperature ranging between 90 and $100^{\circ} \mathrm{C}$, and compaction was successfully conducted with a double drum vibratory road roller. Finally, a pneumatic tyre road roller completed the compaction process. More than 20 asphalt pavement cores were drilled and extracted for each type of asphalt mixture.

These cores were then taken to the laboratory for testing. The volumetric properties of the cores were determined, and they were tested for stiffness modulus at $20^{\circ} \mathrm{C}$, and resistance to fatigue by means of the indirect tensile test (32) at $20^{\circ} \mathrm{C}$ with a loading frequency of $10 \mathrm{~Hz}$ under a controlled stress mode. Thus, the volumetric properties and stiffness modulus could be compared with the mixes manufactured in the laboratory, and the fatigue performance of the HWMRA could be compared with that of the HMA.

\section{RESULTS AND DISCUSSION}

The results are presented for both of the testing phases: the preliminary laboratory study and field experience.

\subsection{Preliminary laboratory study results}

The results of the volumetric properties, stiffness modulus, and water sensitivity tests for the two HWMRA mixes and the reference HMA mix are shown in Table 6. Despite the fact that the HWMRA mixes have high RAP content and that the three mixes have similar void content, the HMA presented a higher degree of stiffness. However, this modulus value for the HMA appears to be excessively high and it should be noted that in post-studies in the field, lower values (3319 MPa) were obtained for the same mix. This could be due to the different compaction method that was used for the specimens tested for stiffness modulus. In terms of water sensitivity, the retained indirect tensile strengths of the HWMRA mixes are slightly lower than those of the HMA. However, the HWMRA mixes would still meet the standard requirement of having a ITSR higher than $85 \%$ (34) and would therefore be suitable options for use in wearing courses.

Figure 4 shows the resistance of the mixtures to permanent deformations when tested in in the wheel tracker. Although the HMA presented higher stiffness than HWMRA (Table 6) - suggesting that the 


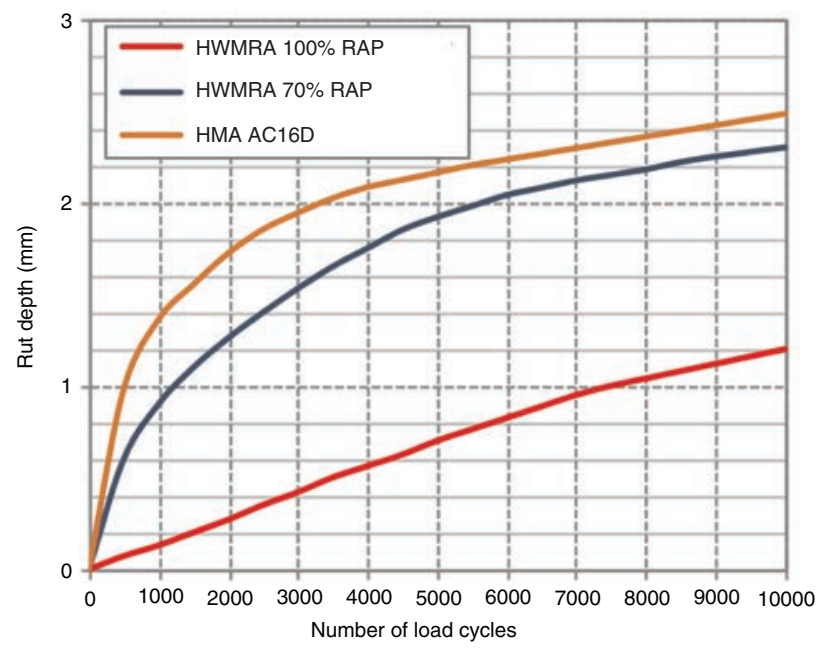

\begin{tabular}{|c|c|c|}
\hline $\begin{array}{c}\text { Typr of } \\
\text { mixture }\end{array}$ & $\begin{array}{c}\text { Max Proportional } \\
\text { Rut depth } \\
\%\end{array}$ & $\begin{array}{c}\text { WTS } \\
\mathrm{mm} \times 10^{-3} \text { load } \\
\text { cycles }\end{array}$ \\
\hline HWMRA 100\% RAP & 190 & 0.082 \\
\hline HWMRA 70\% RAP & 3.80 & 0.088 \\
\hline HMA AC16D & 4.20 & 0.058 \\
\hline
\end{tabular}

FIGURE 4. Resistance to permanent deformation

TABLE 7. Properties of the cores

\begin{tabular}{lccc}
\hline Asphalt Pavement Cores & HWMRA 100 \%RAP & HWMRA 70 \% RAP & HMA AC16D \\
\hline Apparent density, g/cm & 2.306 & 2.280 & 2.305 \\
$\%$ Air void, Vm & 5.5 & 6.3 & 6.3 \\
$\%$ Compaction & 99.2 & 98.5 & 98.5 \\
Modulus at $20{ }^{\circ} \mathrm{C}, \mathrm{MPa}$ & 5820 & 4292 & 2124 \\
\hline
\end{tabular}

HWMRA might have lower resistance to permanent deformations - these materials were considerably more resistant than the HMA. In particular, the slope of the curve for the HMA was steeper, rising sharply during the first 2000 loading cycles, and becoming more stable thereafter. By the end of the test, the three mixes presented equivalent slopes, implying that they are comparable in terms of rutting resistance.

\subsection{Field experience results}

Table 7 shows the volumetric properties and stiffness modulus of the cores of each type of mix. The densities obtained in the field were similar to those obtained in the laboratory. However, in contrast to the results yielded with the laboratory specimens, when tested in the field, the HWMRA achieved a substantially higher degree of stiffness than the HMA. This finding supports the hypothesis that the high stiffness of the HMA found in the laboratory was due to the Marshall compaction procedure. Further, it reinforces the idea that in the field, gyro compaction is more effective at simulating compaction than the Marshall procedure. Finally, it is worth noting that the difference in stiffness between the HMA and HWMRA may be attributed to the differences in binder consistency (the RAP binder had a penetration of $10 \mathrm{dmm}$ while the bitumen

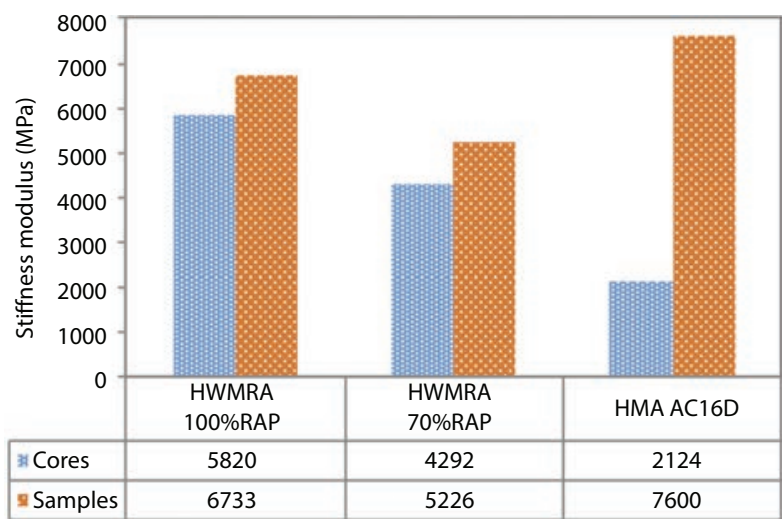

FIGURE 5. Stiffness modulus of laboratory specimens and cores

used for the HMA had a penetration of $42 \mathrm{dmm}$ ). Figure 5 displays the stiffness values for both the laboratory specimens and the cores. It is clear that the HWMRA maintained similar values of stiffness in both the laboratory and field. However, for the HMA, the stiffness modulus values obtained in the field were three times higher than those recorded in the laboratory.

The resistance to fatigue of the cores was assessed through the indirect tensile strength test using controlled stress levels. The failure criterion for fatigue 


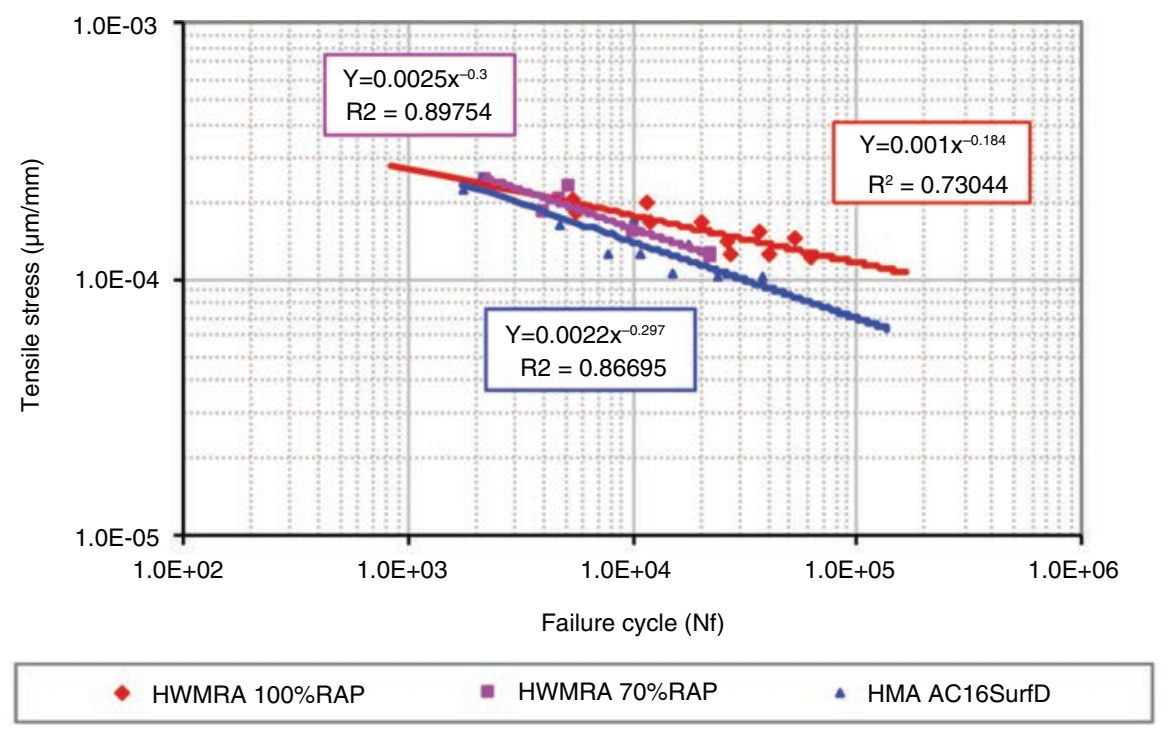

FIGURE 6. Fatigue limits of the cores

was selected as a $50 \%$ reduction of the initial modulus. Figure 6 shows the fatigue laws determined for each type of mixture. The HMA and HWMRA with $70 \%$ RAP show comparable slopes, which suggests that they have an equivalent sensitivity to stress in terms of fatigue life. Thus, taking into account the fact that the fatigue limit of HWMRA with $70 \%$ RAP is higher than that of the HMA, the former appears to have higher resistance to fatigue. The HWMRA with $100 \%$ RAP exhibits a lower slope and therefore shows more stable behaviour in terms of resistance to fatigue. Moreover, for the stress levels tested, the HWMRA with $100 \%$ RAP showed greater fatigue resistance in comparison with both the HWMRA with $70 \%$ RAP and the HMA. Similar results have also been found by other researchers for Warm Mix Asphalt (WMA) containing up to $100 \%$ RAP (15). Thus, it appears that further reducing the manufacturing and compaction temperatures does not adversely affect the advantages of using a WMA with high RAP content.

\section{CONCLUSIONS}

The aim of this paper was to demonstrate the suitability of using Half Warm Mix Recycled Asphalt (HWMRA) with high RAP content (up to $100 \%$ ) manufactured with emulsion for wearing courses. For this purpose, HWMRA mixes were studied in two stages. In the first stage, laboratory specimens were examined, and in the second stage, the mixes were tested at the stages of plant manufacture, and laying and compaction in the field. The results were always compared with those obtained using conventional HMA.

Following laboratory production, the mixes were tested for stiffness modulus, water sensitivity, and resistance to permanent deformations. The following conclusions can be drawn:

- Because of the different values obtained in relation to stiffness modulus (which could be due to the different compaction methods used) it is not possible to draw any firm conclusions regarding the stiffness of HWMRA and HMA.

- Water sensitivity of HWMRA meets the requirements for use in wearing courses.

- HWMRA shows adequate rutting performance.

A prototype plant was able to produce mixes containing up to $100 \%$ RAP using an emulsion at halfwarm temperatures. After laying and compaction in the field, the cores were extracted and their stiffness modulus and fatigue resistance were assessed in the laboratory. The following conclusions can be drawn:

- The stiffness modulus of HWMRA was higher than HMA and similar to the results obtained for laboratory production. Moreover, the density of the cores was also comparable to the laboratory specimens. Therefore, it appears that HWMRA can be successfully reproduced in the plant and compacted without any issue.

- For the stress levels tested, the fatigue performance of HWMRA was satisfactory in comparison to HMA.

In summary, HWMRA showed equivalent performance to HMA, as shown by both the laboratory and field-stage tests. Thus, HWMRA produced with emulsions can be regarded as an environmentally sound alternative to HMA. Moreover, its use should not produce any adverse effects on pavement 
performance. Current research is being carried out in order to further evaluate the long-term performance of this technology.

\section{ACKNOWLEDGEMENTS}

The research presented in this paper was conducted as part of the project LIFESURE, Selfsustaining Urban Roads: A way to improve Environmental performance of urban areas (http:// lifesure.es). The funding for the research was provided by the European Union under the grant agreement number LIFE12 ENV/ES/00072

The authors would also like to express their gratitude to all participants involved in this work project, including the City Hall of Madrid, the Transportation research centre of the Ministry of Public Works (CEDEX) and REPSOL technology.

Furthermore, we would like to thank the European Union's Seventh Framework Programme for Research, Development and Demonstration under the grant agreement number 607524, and the Marie Curie Initial Training Network action (ITN) FP7-PEOPLE-2013-ITN for its financial support.

\section{REFERENCES}

1. Rubio, M.C.; Moreno, F.; Martinez-Echevarria, M.J.; Martinez, G.; Vazquez, J.M. (2013) Comparative analysis of emissions from the manufacture and use of hot and half-warm mix asphalt. J Clean Prod. 41, 1-6. https://doi. org/10.1016/j.jclepro.2012.09.036

2. Ventura, A.; Monéron, P.; Jullien, A.; Tamagny, P.; Zavan, D. (2009) Environmental comparison at industrial scale of hot and half- warm mix asphalt manufacturing processes. Transp Res Board 88th Annu Meet. 12.

3. Pérez, I.; Toledano, M.; Gallego, J.; Taibo, J. (2007) Mechanical properties of hot mix asphalt made with recycled aggregates from reclaimed construction and demolition debris. Mater Construcc. 57 [285] 17-29. http://dx.doi. org/10.3989/mc.2007.v57.i285

4. Li, X.; Clyne, T.R.; Marasteanu, M.O. (2004) Recycled Asphalt Pavement (RAP) Effects on Binder and Mixture Quality. Department of Civil Engineering, University of Minnesota.

5. Hajj, E.Y.; Sebaaly, P.E.; Shrestha, R. (2009) Laboratory Evaluation of Mixes Containing Recycled Asphalt Pavement (RAP). Road Mater Pavement Des. 10, 495-517. https://doi.org/10.1080/14680629.2009.9690211

6. Shah, A.; McDaniel, R.; Huber, G.A.; Gallivan, V.L. (2007) Investigation of Properties of Plant-Produced Reclaimed Asphalt Pavement Mixtures. Transp Res Rec J Transp Res Board. 1998, 103-111. https://doi.org/10. 3141/1998-13

7. Shu, X.; Huang, B.; Vukosavljevic, D. (2008) Laboratory evaluation of fatigue characteristics of recycled asphalt mixture. Constr Build Mater. 22, 1323-1330. https://doi. org/10.1016/j.conbuildmat.2007.04.019

8. Huang, B.; Zhang, Z.; Kingery, W.; Zuo, G. (2004) Fatigue crack characteristics of HMA mixtures containing RAP. Fifth Int RILEM Conf Reflective Crack Pavements. pp 631-638.

9. McDaniel, R.S.; Shah, A.; Huber, G.A.; Copeland, A. (2012) Effects of reclaimed asphalt pavement content and virgin binder grade on properties of plant produced mixtures. Road Mater Pavement Des. 13, 161-182. https://doi. org/10.1080/14680629.2012.657066
10. Tabaković, A.; Gibney, A.; McNally, C.; Gilchrist, M.D. (2010) Influence of Recycled Asphalt Pavement on Fatigue Performance of Asphalt Concrete Base Courses. J Mater Civ Eng. 22, 643-650. https://doi.org/10.1061/(ASCE) MT.1943-5533.0000093

11. Kristjánsdóttir, Ó.; Muench, S.; Michael, L.; Burke, G. (2007) Assessing Potential for Warm-Mix Asphalt Technology Adoption. Transp Res Rec J Transp Res Board. 2040, 91-99. https://doi.org/10.3141/2040-10

12. Coppola, L.; Kara, P.; Lorenzi, S. (2016) Concrete manufactured with crushed asphalt as partial replacement of natural aggregates. Mater. Construcc. 66, 1-7. https://doi. org/10.3989/mc.2016.06515

13. Swaroopa, S.; Sravani, A.; Jain, P.K. (2015) Comparison of mechanistic characteristics of cold, mild warm and half warm mixes for bituminous road construction. Indian $J$ Eng Mater Sci. 22, 85-92.

14. Chang-fa, A.; Bao-xian, L.; Hao, P.; Yan-jun, Q. (2014) Study of Strength Forming Mechanism and Influencing Factors of Half-warm Mix Asphalt. J Highw Transp Res Dev. 8, 1-6.

15. Dinis-Almeida, M.; Castro-Gomes, J.; Sangiorgi, C.; Zoorob, S.E.; Afonso, M.L. (2016) Performance of Warm Mix Recycled Asphalt containing up to 100\% RAP. Constr Build Mater. 112, 1-6. https://doi.org/10.1016/j. conbuildmat.2016.02.108

16. Zhao, S.; Huang, B.; Shu, X.; Woods, M. (2013) Comparative evaluation of warm mix asphalt containing high percentages of reclaimed asphalt pavement. Constr Build Mater. 44, 92-100. https://doi.org/10.1016/j. conbuildmat.2013.03.010

17. Zhao, S.; Huang, B.; Shu, X.; Jia, X.; Woods, M. (2012) Laboratory Performance Evaluation of Warm-Mix Asphalt Containing High Percentages of Reclaimed Asphalt Pavement. Transp Res Rec J Transp Res Board. 2294, 98-105. https://doi.org/10.3141/2294-11

18. Copeland, A.; D'Angelo, J.; Dongre, R.; Belagutti, S.; Sholar, G. (2010) Field Evaluation of High Reclaimed Asphalt Pavement-Warm-Mix Asphalt Project in Florida. Transp Res Rec J Transp Res Board. 2179, 93-101. https:// doi.org/10.3141/2179-11

19. EN 12697-1 (2012) Bituminous mixtures - Test methods for hot mix asphalt Part 1: Soluble binder content. European Standards.

20. EN 12697-4 (2005) Bituminous mixtures - Test methods for hot mix asphalt — Part 4: Bitumen recovery: Fractionating column. European Standards.

21. EN 933-3 (2012) Tests for geometrical properties of aggregates Part 3: Determination of particle shape - Flakiness index. European Standards.

22. EN 1426 (2007) Bitumen and bituminous binders Determination of needle penetration. European Standards, $\mathrm{p} 18$.

23. EN 993-5 (2000) Methods of test for dense shaped refractory products. Part 5: Determination of cold crushing strength. European Standards.

24. EN 1427 (2007) Bitumen and bituminous binders Determination of the softening point — Ring and Ball method. European Standards, p 18.

25. EN 933-8 (2012) Tests for geometrical properties of aggregates Part 8: Assessment of fines — Sand equivalent test. European Standards.

26. EN 12697-26 (2012) Bituminous mixtures — Test methods for hot mix asphalt Part 26: Stiffness. European Standards.

27. EN 933-9 (2009) Tests for geometrical properties of aggregates. Part 9: Assessment of fines - Methylene blue test. European Standards.

28. EN 12697-23 (2003) Bituminous mixtures - Test methods for hot mix asphalt - Part 23: Determination of the indirect tensile strength of bituminous specimens. European Standards.

29. EN 1097-2 (1998) Tests for mechanical and physical properties of aggregates - Part 2: Methods for determination of bulk density and intergranular porosity. European Standards.

30. EN 12697-22 (2003) Bituminous mixtures - Test methods for hot mix asphalt — Part 22: Wheel tracking. European Standards. 
10 J.M. Lizárraga et al.

31. EN 1097-6 (2013) Tests for mechanical and physical properties of aggregates. Part 6: Determination of particle density and water absorption. European Standards.

32. EN 12697-24 (2012) Bituminous mixtures - Test methods for hot mix asphalt.. Part 24: Resistance to fatigue. European Standards, pp 1-62.
33. EN 13074-1 (2011) Bitumen and bituminous binders Recovery of binder from bituminous emulsion or cut-back or fluxed bituminous binders Part 1: Recovery by evaporation. European Standards.

34. Pliego de Prescripciones Técnicas Generales para Obras de Carreteras y Puentes (PG-3). Articulo 542 (2004). 